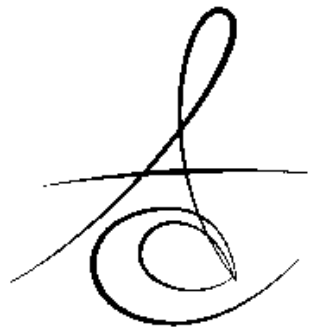

\title{
BAŞ BOYUN BÖLGESİNDEKİ YUMUŞAK DOKU KALSİFİKASYON VE OSSİFİKASYONLARI
}

\section{SOFT TISSUE CALCIFICATION AND OSSIFICATION IN THE HEAD AND NECK REGION}

\author{
Doç. Dr. Derya YILDIRIM*
}

Arş. Gör. Dt. Elif BİLGİR*

Makale Kodu/Article code: 2043

Makale Gönderilme tarihi: 24.12.2014

Kabul Tarihi: 17.11.2015

\section{ÖZET}

Çene-yüz bölgesinde nadir olarak görülen yumuşak doku kalsifikasyon ve ossifikasyonları genellikle rutin radyografik tetkikler sırasında tesadüfen fark edilirler. Kalsifikasyonlar; distrofik, idiyopatik ve metastatik olmak üzere sınıflandırılabilir. Ossifikasyonlar; stylohyoid ligament ossifikasyonu, osteoma kutis, myositis ossifikanstır. Kalsifikasyon ve ossifikasyonlar, bazı durumlarda semptomatik olabilmelerine karşın çoğunlukla uzun yıllar semptomsuz kalırlar. Anatomik lokalizasyonları, dağıımı, sayısı, ebatları ve şekli en önemli tanı kriterleridir. Radyograflarda belirlenen yumuşak doku kalsifikasyonlarının lokalizasyonlarının belirlenebilmesi, normal ve patolojik anatominin detaylı olarak incelenebilmesi amacılla bilgisayarı tomografi, konik ışınlı bilgisayarlı tomografi, manyetik rezonans görüntüleme ve ultrasonografi ile değerlendirme gerekebilmektedir. $\mathrm{Bu}$ derlemede yumuşak doku kalsifikasyon ve ossifikasyonları genel özelliklerine göre sınıflandırılmış, klinik ve radyografik özellikleriyle tartışıımışır.

Anahtar Kelimeler: Kalsifikasyon, ossifikasyon, panoramik radyografi, distrofik

\section{GİRİŞ}

İskelet sisteminde depolanan kalsiyum tuzlarının çeşitli sebeplerle yumuşak dokularda organize olmayan birikimi heterotopik kalsifikasyon, organize bir şekilde birikmesi heterotopik ossifikasyon olarak adlandırıır $^{1,2}$. Bu lezyonlar oluşum mekanizmaları, etiyolojileri ve lokalizasyonlarına göre alt gruplara ayrilır, ${ }^{3,4}$. Baş boyun bölgesindeki yumuşak dokularda oluşan birçok kalsifikasyon ve ossifikasyon radyoopak izlenir. Bu lezyonlar sıkıkla diş hekimlerinin teşhis ve tedavi

\section{ABSTRACT}

Soft tissue calcifications and ossifications in the maxillofacial area are uncommon, and generally they are noticed in routine radiographic examinations. Calcifications can be classified as dystrophic, idiopathic and metastatic. Ossifications can be classified as stylohyoid ligament ossification, osteoma cutis, myositis ossificans. Calcifications and ossifications can be symptomatic or they can remain asymptomatic for years. The most important diagnostic criterions of the calcifications are anatomical location, distribution, number, size and shape. To determine the localization of soft tissue calcifications identified in radiographs and in order to examine the normal and pathological anatomy in detail, computed tomography, cone beam computed tomography, magnetic resonance imaging and ultrasonography is performed. In this review, these calcifications and ossifications are classified as regards general characteristics, their clinical and radiographic features are discussed.

Keywords: Calcification, ossification, panoramic radiography, dystrophic

planlaması amacıyla aldıkları panoramik radyograflarda tesadüfen fark edilirler. Yumuşak doku kalsifikasyon ve ossifikasyonlarının prevalansları ile ilgili çeşitli araştırmalar mevcuttur. Garay ${ }^{5}$ ve arkadaşları 2014 yilında Şili'de, yaptıkları bir çalışmada inceledikleri panoramik radyografların \% 2,61'inde kalsifikasyon belirlediler ve bunlardan \% 56'sının tonsilolit, \%29'unun karotis arter kalsifikasyonu, $\% 11^{\prime}$ inin tükürük bezi taşı ve $\% 4^{\prime}$ 'ünün lenf nodu kalsifikasyonu olduğunu bildirdiler. Ergun ${ }^{6}$ ve arkadaşları 2013 yılında Türkiye'de travma sonrası başvuran 357 hastanın bilgisayarlı tomografi (BT) görüntülerini incelemiş ve $\% 22,9$ oranında karotis

*Süleyman Demirel Üniversitesi, Diş Hekimliği Fakültesi, Ağız, Diş ve Çene Radyolojisi, Anabilim Dalı 
arter kalsifikasyonu, \%32,2 oranında tonsilolit, \%24,3 oranında stilohyoid ligament kalsifikasyonu belirlemişlerdir. Kalsifikasyon ve ossifikasyonların klinik ve radyografik özelliklerinin bilinmesi hem ayırıcı tanıda hekimlerin işini kolaylaştıracak hem de kalsifikasyon ve ossifikasyon oluşumuna neden olan sistemik hastaIıkların belirlenmesi ve gerekli önlemlerin alınmasını sağlayacaktır ${ }^{7}$. Bu derlemede güncel literatür bilgisi ışığında yumuşak doku kalsifikasyon ve ossifikasyonları vaka örnekleriyle birlikte klinik ve radyografik özellikleri ile incelenmiş, ayırıcı tanı ve tedavileri açısından değerlendirilmiştir.

\section{HETEROTOPİK KALSİFİKASYONLAR}

Heterotopik kalsifikasyonlar; distrofik, idiyopatik ve metastatik olmak üzere sınıflandırılabilir.

\section{Distrofik Kalsifikasyonlar}

Serum kalsiyum ve fosfat seviyeleri normal bireylerde, dejeneratif ve ölü dokularda meydana gelir ve patolojiktir. Genellikle enflamasyon, travma, enfeksiyöz hastalıkları takiben oluştukları düşünülür ${ }^{1-3}$. Başboyun bölgesinde diş hekimlerinin sıklıkla karşılaştıkları kalsifiye lenf nodları, tonsilolit, sistiserkoz ve arteriyel kalsifikasyonlar distrofik kalsifikasyonlara örnektir.

Kalsifiye Lenf Nodları; lenf nodu dokusunun hidroksiapatit kristalleri ile yer değiştirmesi sonucu meydana gelir. En yaygın sebebi tüberkülozdur. Bunun dışında BCG aşısı, sarkoidoz, kedi tırmığı hastalığı, radyasyon terapisi yapılan lenfoma, mantar enfeksiyonlarını takiben ve kalsifiye neoplazmların metastazı sebebiyle de görülebilir ${ }^{3,8-10}$. Lenf nodu kalsifikasyonları genellikle asemptomatiktir, çoğunlukla panoramik radyograflarda tesadüfen fark edilir. En yaygın submandibular ve servikal lenf nodlarında görülür. Radyografide sıklıkla ramusun altında, submandibular bölgede tek veya lenf nodu zinciri boyunca çok sayıda, yuvarlak, sınırları belirgin ve düzensiz, karnıbahar görünümünde, lobule radyoopak kitleler halinde görülür (Şekil 1) ve siyalolit ya da flebolit ile karıştırılabilir ${ }^{3}$. Siyalolitin düzenli sınırlanması ve semptomatik olmasıyla ayırtedilebilir. Ayırıcı tanıda siyalografiden de faydalanılabilir ${ }^{10}$. Lenf nodu kalsifikasyonları çoğunlukla tedavi gerektirmez ancak belirlendiğinde, altta yatan sebebi bulmak gerekir. Metastatik lenf nodları primer tümörün yeri hakkında bilgi verir. Bu durumda ileri görüntüleme yöntemleriyle inceleme hem prognozun hem de tedavi prosedürünün belirlenmesi için faydalı olacaktır ${ }^{8}$.
Tonsilolit; genellikle tekrarlayan enflamasyonları takiben oluşur ve sıklıkla yetişkinlerde görülür. Tek ya da çok sayıda olabilir. Tonsiller kriptlerin üzerinde sarı veya beyaz renkli, sert, yuvarlak kitle olarak görülür (Şekil 2). Klinik olarak kronik boğaz ağrısı, öksürük, yutma güçlüğü, ağız kokusu, kötü tat ve yabancı madde hissi gibi belirtiler görülebilir. Büyük boyutlara ulaşırsa lenfoid dokularda ülserasyona sebep olabilir $^{2,7}$. Panoramik radyografta tek veya çok sayıda, orofaringeal hava yolu civarında, mandibula ramus üzerine süperpoze radyoopasiteler şeklinde görülür. Dansitesi kemik dansitesinden daha yoğundur, en yaygın görünümü multiple, küçük, düzensiz salkım şeklinde görülen radyoopasitelerdir (Şekil 3). Klinik muayene ve bulgular tanıda önemlidir. Ayırıcı tanıda kemikteki osteoskleroz ve enostozlar, kalsifiye granüloma, siyalolit, malignansi, flebolit, sifilizin üçüncü evresi düşünülebilir ${ }^{1-3}$. Tonsilolit teşhis edildikten sonra tek sayıda ve büyük boyuttaysa çıkartılmalıdır. Fakat çok sayıda ve ulaşılması güç olan tonsilolitler takip altında tutulur, ancak çok büyük boyutlara ulaşırsa ve semptomatik hale gelirse çıkarılması gerekebilir².

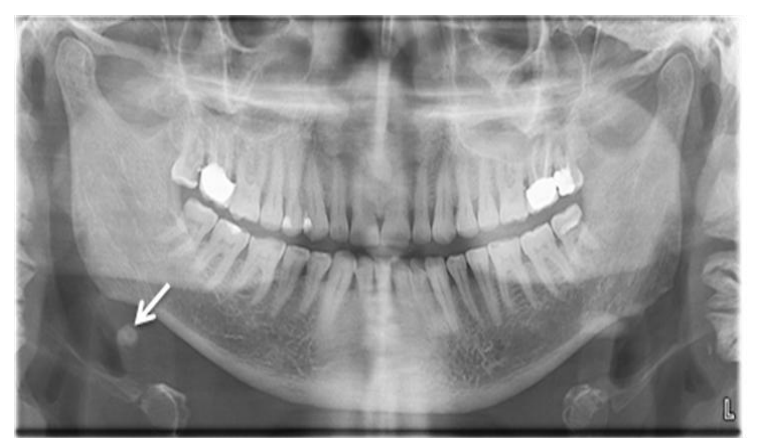

Şekil 1. Kliniğimize muayene olmak için gelen hastanın panoramik radyografında sağ angulus mandibula altında radyoopasite (ok) izlenmiştir. Anamnezinde 20 yıl önce tüberküloz geçirdiği öğrenilen hastadan USG alınmış ve lenf nodu kalsifikasyonu olduğu doğrulanmıştır. 


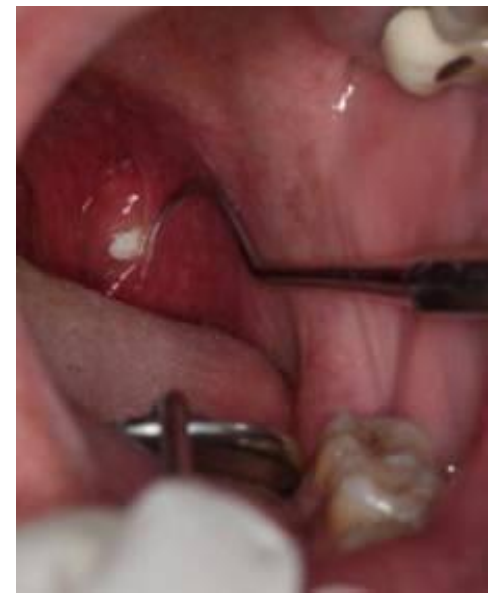

Şekil 2. Kliniğimizde teşhis edilen; sol tonsiller kript üzerindeki tonsilolit.

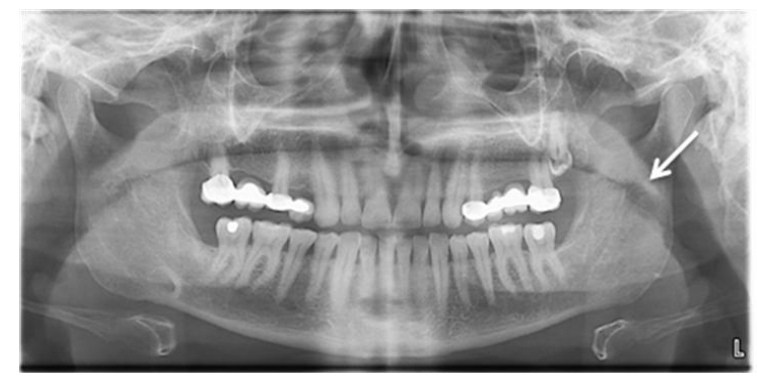

Şekil 3. Kliniğimizde muayenede tonsilolit belirlenen hastanın panoramik radyografında, sol mandibula ramus bölgesine süperpoze (ok) radyoopasite izlenmiștir. Anamnezi derinleştirilen hastanın sık sık farenjit geçirdiği öğrenilmiştir.

Sistiserkoz; tenya solyum yumurtalarının kan ve lenf yoluyla tüm vücuda yayılıp, bulundukları bölgede ölen larvaların kalsifikasyonu ile ortaya çıkan durumdur. En yaygın lokalizasyonu, beyin ve gözü takiben subkütanöz dokular ve kaslardır. Oral bölgede çiğneme kaslarında, dil ve dudaklarda meydana gelebilir $^{11,12}$. Oral mukoza yerleşimliyse palpasyonda sınırları belirgin, multiple küçük nodüller hissedilir. Bazı olgularda ateş rapor edilmiştir. Radyografik olarak çok sayıda, sınırları düzenli, pirinç tanesi şeklinde görülür. Ayırıcı tanıda siyalolit, lenfadenopati, yumuşak doku enflamasyonları akla gelir. Fakat boyutlarının küçük olması ve yaygın dağılımı ile diğer lezyonlardan ayrılır 3,13,14. İnce iğne aspirasyon yöntemiyle kesin tanı koyulur. Tedavisinde semptomatik olarak antihelmentik ilaçlar kullanılır ${ }^{14,15}$.

Arteriyel Kalsifikasyonlar; yaşlanma, diyabet, genetik bozukluklar, dislipidemi, kalsiyum metabolizması bozuklukları sonucunda damarlarda kalsifikasyon görülebilir. Bu kalsifikasyonlardan tunika media yerleşimli olan arteriyosklerozis; intima yerleşimli olan kalsifiye aterosklerotik plak olarak adlandırılır ${ }^{16}$. Etiyolojilerinde kan basıncı artışı, yüksek serum kolesterol ve karbonhidrat seviyeleri ve endotelyal hasara neden olabilecek diğer sistemik faktörler düşünülmektedir. Taguchi ${ }^{17}$ ve arkadaşları 2013 yılında yaptıkları bir çalışmada karotis arter kalsifikasyonu olan hastaların \%2,45'inde osteoporoz belirlemişlerdir. Tiller $^{18}$ ve arkadaşları da 2011 yılında yaptıkları bir çalışmada periodontal riski yüksek olan hastalarda karotid bölge kalsifikasyonlarına daha fazla rastlandığını bulmuşlar ve bu durumu diyabetes mellitus ve sigara kullanımıyla ilişkilendirmişlerdir.

-Arteriyosklerozis: Sıklıkla kalpten daha distaldeki ve muskuler arterlerin tunika mediasında meydana gelen kalsifikasyonları ifade eder. Kalsifiye aterosklerotik plağa göre daha benign bir durumdur. Ancak diyabetes mellitus, osteoporoz ya da hiperparatiroidizm gibi hastalıklarla ilişkili olabilir. Başlangıçta asemptomatik olmasına rağmen kütanöz gangren, periferal vasküler hastalık, myosit gibi durumlarla sonuçlanabilir ${ }^{16,19}$. Panoramik radyograflarda daha sık fasiyal arterde, daha az olarak da karotid arterde, damarın dış duvarı boyunca boru-gövdesi ya da tren yolu olarak adlandırılan bir opasite şeklinde görülürler ve bu görünüm patognomoniktir ${ }^{3,20}$.

-Kalsifiye Aterosklerotik Plak: Kan basıncı artışı, yüksek serum kolesterol ve karbonhidrat seviyeleri ve diğer faktörler endotelyal hasara ve aterogeneze neden olur. Bu hasar alanlarında plak birikip, kalsifiye olabilir ${ }^{21}$. Karotis arterdeki plaklar sıklıkla bifürkasyon bölgesinde yer alır, kalsifiye plaklar radyografta görülebilir ${ }^{22,23}$. Doppler ultrasonografi (USG), manyetik rezonans görüntüleme (MRG) ve BT gibi non-invaziv ve subtraksiyon anjiyografisi gibi invaziv tekniklerle incelenebilir. Özellikle serebral arterlerdeki plaklar emboli ataklarına ve ciddi sonuçlara neden olabilir $^{23}$. Dişhekimlerinin muayenelerinde sıkça başvurdukları panoramik radyograflarda bu kalsifikasyonlar sıklıkla servikal 3. vertebraların arasındaki boşluklarda ya da hyoid kemiğin kornu majus kısmına komşu boyun bölgesinde izlenir ${ }^{3,21}$. Konik ışınlı bilgisayarlı tomografi'de (KIBT) karotis arterin bulunduğu alanlarda; pirinç tanesi şeklinde ya da linear dizilimli kalsifikasyonlar belirlenebilir. KIBT ile süperpozisyonlardan uzak üç boyutlu görüntüler elde edileceğinden panoramik radyografiden daha değerli bilgi

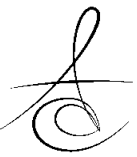


edinilebilir ${ }^{23}$. Imanimoghaddam ${ }^{24}$ ve arkadaşları 2011 ylında yaptıkları bir çalışmada 960 panoramik radyograftan 19'unda karotid arterde kalsifiye aterosklerotik plak belirlediler ve bu hastalardan 16'sına ilave inceleme yapıldı. Doppler USG ile yapılan incelemede 12 hastada kalsifiye aterosklerotik plak varlığı belirlendi. Bu nedenle dişhekimleri bu kalsifikasyonlardan şüphelendiğinde hastaları mutlaka kardiyoloji ile konsulte etmelidir. Ayırıcı tanıda tritiseöz kartilajin kalsifikasyonu düşünülebilir; ancak bu kalsifikasyonlar panoramik radyografta daha lateralde görülür? ${ }^{3}$.

\section{İdiyopatik Kalsifikasyonlar}

Normal serum kalsiyum ve fosfat seviyelerine rağmen normal dokularda meydana gelen kalsifikasyonlardır ${ }^{1}$.

Siyalolitler; tükürük bezlerinde veya kanallarının distal bölgelerinde meydana gelir. Tükürük akış hızını azaltan mekanik şartlar ve sekresyonun fizyokimyasal karakteri hem odak oluşumuna hem de kalsiyum ve fosfat tuzlarıın çökelmesine olanak sağlar ${ }^{3}$. En sık submandibular bezde (\%80-90), sonra parotis bezinde (\%5-10) en az da sublingual bezler ve minör tükrük bezlerinde rastlanır ${ }^{25}$. Tek veya çok sayıda olabilir. Hastalar genellikle asemptomatik olmasına rağmen, şişlik ve ağrı gibi şikayetler duruma eşlik edebilir. Tükürük akışı stimüle edildiğinde bu şikayetler artacaktır. Submandibular siyalolitler lenfadenopatiyle karışabilir, bimanuel palpasyon ayıııı tanıda yardımc olur $^{3,26}$. Radyografta genellikle silindirik radyoopasiteler şeklindedir, submandibular bezdeki taşlar genellikle daha uzun ve düzensiz şekillidirler (Şekil 4). Bu taşlar ilgili bölgeden alınan bir periapikal ve okluzal filmle lokalize edilebilir ${ }^{3}$. Tükürük bezleri radyografik olarak iki boyutlu yöntemler, USG, BT, MRG ve siyalografi ile görüntülenebilir. Görüntüleme yöntemleri farklı avantajlara sahiptir. USG ucuz ve güvenilir bir görüntüleme yöntemidir. Ancak kalsifikasyonun net görüntülenmesine ve bezdeki hasarın belirlenmesine olanak sağlayamaz. BT ile kalsifikasyonun şekli tam olarak belirlenebilirken yine bezdeki hasar hakkında bilgi edinilemez. MRG ikisinin de aksine bezdeki hasarı ortaya koyar, ancak kalsifikasyonun net şekli belirlenemez. Siyalografi fonksiyonel bir görüntüleme yöntemidir hem bez hem de kalsifikasyon ya da daralma hakkında nispeten iyi bir bilgi elde edilir. KIBT'nin diş hekimliğinde yaygın kullanılmaya başlanması siyalografi uygulamalarının üç boyutlu olarak da gerçekleştirilmesine olanak sağlamışır. Ayrıca günümüzde siyaloendoskopi ile de bezin lümeni ve tıkanmanın sebebi incelenebilmektedir ${ }^{25-28}$. Küçük taşlar bimanuel palpasyonla çıkarılabilir, eğer taşlar daha büyük ve derin yerleşimli ise ve semptomatik hale gelirse ESWL (piezoelektrik ekstrakorporeal shock wave lithotripsy) ile kırılabilir ya da cerrahi olarak taş ve bezin çıkartılması gerekebilir ${ }^{3}$. Semptomlar lenf nodu kalsifikasyonu ve bezlerin lokalizasyonundaki diğer kalsifikasyonlarla ayırıcı tanıda önemlidir. Siyalografi ya da USG ile tanı koyulur ${ }^{3,29}$.

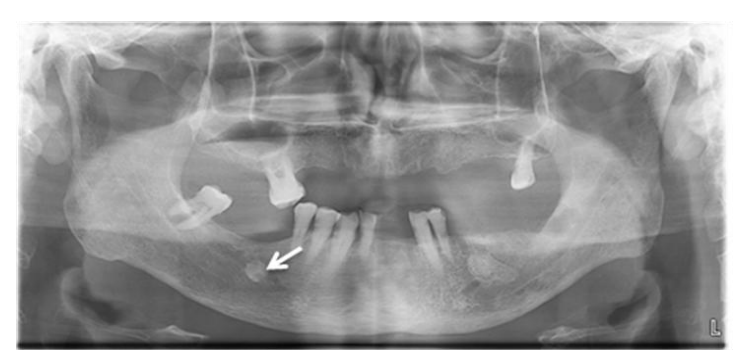

Şekil 4. Kliniğimize muayene olmak için gelen hastanın panoramik radyografinda sağ mandibula molar diş bölgesine süperpoze radyoopasite (ok) izlenmiş, aktif şikayeti olmayan hastadan USG istenmiş ve siyalolit olarak doğrulanmıştır.

Flebolit; venlerde, venüllerde veya hemangioma damarlarının sinuzoidal boşluklarında, kan akışının azalması sonucu oluşan intravasküler trombüslerin organize olup kalsiyum, fosfat kristallerinin çökelmesiyle meydana gelir ${ }^{3,30}$. Baş boyun bölgesindeki flebolitler sıklıkla hemangiomalarla ilişkilidir. Flebolit, bir ven ya da yumuşak dokudaki hemanjiyomadan kaynaklıysa, klinik olarak deride renk değişikliği, şişlik, pulsasyon, diaskopide beyazlaşma gözlenir; kavernöz tipte oskültasyona cevap gibi belirtiler görülebilir. Radyografta homojen bir radyoopasite vardır, laminasyon görülebilir, bu görünümü hedef tahtasına benzetilir. Merkezi, bir damardan ötürü radyolüsent görülebilir (Şekil 5) ) $^{3,31,32}$. Siyalolit ile ayırıcı tanı koyulmalıır. Klinik bulgular, radyografta çok sayıda, rastgele dizilim göstermesi ve genelde hemanjiyomalarla birlikte görülmesi, siyalolit ve diğer kalsifikasyonlardan ayrılmasında önemlidir ${ }^{30}$. 


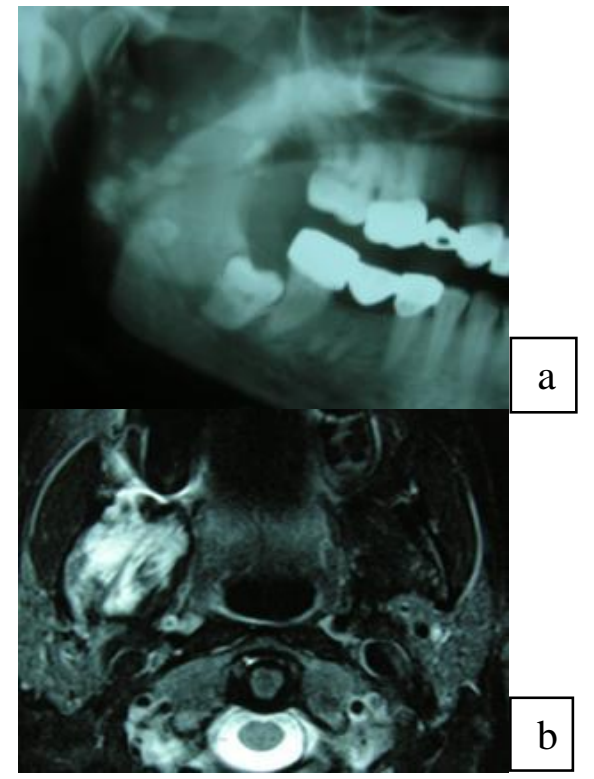

Şekil 5 a/b: Daha önceden başka bir merkezde flebolit tanısı koyulan hastanın panoramik radyografı ve manyetik rezonans görüntülemede aksiyal kesit görüntüsü.

Laringeal Kartilaj Kalsifikasyonu; larinksin yapısında krikoid, tiroid, epiglottik, kornikulat, kuneiform, tritiseöz ve sesamoid kıkırdaklar bulunur ${ }^{33}$. Epiglottik kıkırdak dışındaki laringeal kıkırdakların büyük kısmı hiyalin kıkırdaktan oluşur ve hiyalin kıkırdak ilerleyen yaşla birlikte kalsifiye olabilir. Bu kalsifikasyonun mekanizması hakkında Galline ve arkadaşları ${ }^{34}$ tekrarlayan mikrotravmaların ya da tendonlarda ossifikasyon başlatabilecek ekstralaringeal kasların aşııı kullanımının etken olabileceği hipotezini ileri sürmüşlerdir. Kadınlarda daha sık görülür, her iki cinsiyette de kalsifikasyon yaşla artar, en sık tiroid kıkırdakta görülür, genellikle simetriktir ${ }^{35}$. Klinik olarak asemptomatiktirler, rutin radyografik tetkikler esnasında tesadüfen fark edilirler. Panoramik radyograflarda kalsifiye tritiseöz kıkırdak 4. servikal vertebraların üstünde, faringeal hava boşluğunun yanında, pirinç tanesi şeklinde gözlenirken; kalsifiye tiroid kıkırdak 4. servikal vertebranın medialinde ve intervertebral yumuşak dokular üzerine süperpoze, sınırları düzenli radyoopasiteler şeklinde görülür ${ }^{3}$.

Kıkırdak kalsifikasyonlarında tedaviye gerek yoktur. Ancak kondroid lezyonlarla karışabilmesi intimaline karşın fark edildiklerinde takip randevusu verilerek boyutsal değişim olup olmadığının incelenmesi gerekir. Ayrıca kalsifiye aterosklerotik plakla aynı lokalizasyonda görülebildikleri için karıştırılabilirler. Radyograflarda bu plaklar daha heterojen görünüm verirler, gerekli durumlarda USG ya da MRG ile detaylı inceleme yapılabiliir,34.

Rinolit/Antrolit; endojen ya da eksojen kaynaklı bir odağın etrafında mineral tuzlarının birikimiyle burunda oluşan taşlar rinolit, sinüste oluşan taşlar antrolit olarak adlandırılır. Rinolit genellikle bozuk para, boncuk, meyve çekirdeği, kalmış bir gazlı bez tamponu gibi yabancı maddelerin etrafında, antrolit ise diş kökü, kemik fragmanı kan pıhtısı gibi endojen kaynaklı bir odağın etrafında oluşur ${ }^{36}$. Klinik olarak genellikle asemptomatiktir, büyük boyutlara ulaşınca ülserasyon, baş ve yüzde ağrı, tek taraflı burun akıntısı, tek taraflı pürülan rinit ya da sinüzit, dakriyosistit, kulak akıntısı, koku duyusunda bozulma gibi belirtiler görülebilir ${ }^{3,37-39}$. Odağın yapısına bağlı olarak homojen ya da heterojen bir radyoopasite şeklinde görülürler. Bazen laminasyon olabilir, bu durumda dansitesi komşu kemikle karışır ${ }^{3}$. Rinolit en sık nasal kavitenin tabanında, meatus nasi inferiorda görülür ${ }^{40}$. Water's projeksiyonu ile görüntüleme mümkündür. Ancak üç boyutlu görüntüleme her ikisi için de diagnostiktir ${ }^{37}$.

\section{Metastatik Kalsifikasyonlar}

Serum kalsiyum ve fosfat seviyelerinin yükselmesine neden olan ve nadir görülen malign hiperkalsemi ya da hiperparatiroidizm gibi durumların sonucu olarak görülür ${ }^{1,3}$.

Hiperparatiroidizm; parathormon salgısının artmasıyla karakterize, kemik mineral dansitesinde azalmaya ve kan kalsiyum miktarında artışa neden olan metabolik endokrin bir bozukluktur. Çoğunlukla paratiroid bezdeki adenom, hiperplazi ya da tümörler nedeniyle primer olarak; nadiren de hipokalsemiye sekonder olarak karşımıza çıkar ${ }^{41-43}$. Uzun dönem sekonder hiperparatiroidizmin devam etmesi sonucunda tekrar hiperkalsemi oluşmaya başlar, bu dönemdeki hiperparatiroidizm ise tersiyer olarak adlandırlır $^{43}$. Parathormon'un aşırı salgılanması sonucunda iskelet sistemindeki etkileri klinik olarak artralji, kemik ağrıları, patolojik kırıklar ve Brown tümörler şeklinde görülür. Artmış kan kalsiyum düzeyi gastrik asit salgısını uyarır. Dolayısıyla bu hastalarda peptik ülsere sık rastlanır. İdrar ve tükürükte fosfat ve kalsiyum konsantrasyonu arttı̆ı̆ı için taş oluşabilir ${ }^{44}$. Ayrıca hiperkalsemi nedeniyle özellikle panoramik radyograflarda fark edilebilecek olan karotid arter kalsifikasyonlarında da hiperparatiroidizm akla gelmelidir ${ }^{16}$. 


\section{HETEROTOPİK OSSİFİKASYONLAR \\ Stilohyoid Ligament Ossifikasyonu;}

stilohyoid kompleks; stiloid çıkıntı, stilohyoid ligament ve hyoid kemiğin kornu kısmından oluşur ${ }^{45,46}$. Bu kompleks; stilomastoid foramenin önünde internal ve eksternal karotid arter ile internal jugular ven arasında yer alır. Temporal kemikte ince, uzun, silindirik bir şekildedir. Yaklaşık uzunluğu $2,5 \mathrm{~cm}$ 'dir. Stylohyoid ligament kompleksinin daha uzun olması ya da stylohyoid ligamentin ossifikasyonu patolojik olarak değerlendiriliı ${ }^{46,47}$. Genellikle kafatası tabanından aşağıya doğru bir ossifikasyon izlenmesine rağmen, nadir olarak ossifikasyon hyoid kemikten başlayıp ligamentin merkezine doğru ilerleyebilir. Sıklıkla bilateraldir. Klinik olarak çoğunlukla asemptomatiktir. Tonsillerin üzerinden sert bir kitle şeklinde palpe edilebilir $^{3}$. Kalsifiye stylohyoid ligament; genellikle daha önceden tonsillektomi veya boyun bölgesinde travma hikayesi olan bireylerde, skar dokusu ile birlikte etrafındaki nöro-vasküler yapılar (muhtemelen glossofaringeal sinir) üzerinde basınç meydana getirebilir. Bu durumda yutkunmada ağrı, yutkunma bozukluğu, farinkste yabancı madde hissi, kulak ve baş ağrısı, rotasyonda ve ağız açmada boyun ağrısı gibi klinik belirtilerle karakterize Eagle's sendromu ortaya çıkar ${ }^{48}$. Eğer travma hikayesi yoksa aynı klinik bulgular stilohyoid (karotid arter) sendrom olarak adlandırlır. Bu hastalarda ağrı arter duvarındaki sempatik sinirlerin uyarıması sonucunda meydana gelir ${ }^{3}$. Radyograflarda düzgün sınırlı, ince, uzun, radyoopak bir hat şeklinde görülür ve bazı bölgelerde radyolüsent kesintilerle birlikte psödoartikülasyon görünümü ortaya çıkabilir (Şekil 6). Ayırıcı tanıda; nevralji tipi ağrılar, TME rahatsızlıkları, tonsillit, farenjit, diş ağrıları akılda tutulmalıdır ve görüntüleme (Şekil 7) teşhiste yardımcı olacaktır. Semptomatik vakalarda cerrahi yöntemlere başvurulur ${ }^{13}$.

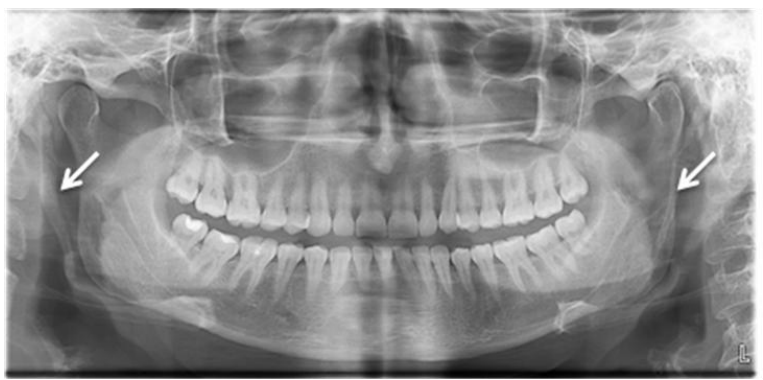

Şekil 6. Kliniğimize diş sıkma ve dişeti kanaması şikayetiyle başvuran hastanın panoramik radyografında tesadüfen fark edilen stilohyoid ligament ossifikasyonu (ok).

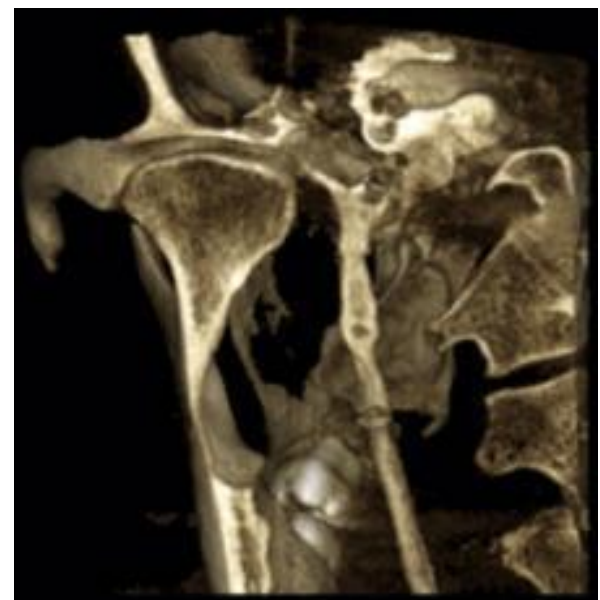

Şekil 7. Aynı hastanın sol foramen mandibulasında fark edilen genişleme nedeniyle alınan KIBT'de kalsifiye stilohyoid ligamentin görüntüsü.

Osteoma Kutis; nadir olarak görülen, bir yumuşak doku ossifikasyonudur. Etiyolojisi açık değildir. Genellikle skleroderma, pilomatrisoma, bazal hücreli karsinoma, skarlar, enflamasyon, travma, fibröz proliferasyon ya da venöz stazlara sekonder olarak gelişir. Başka bir durumla ilişkilendirilemediğinde de primer lezyonlardan söz edilir. Bazı otörler bu hastalı̆ı endometriyozis, menstrüal döngü dışındaki uterus kanamaları, hiperparatiroidizme bağı metastatik kalsifikasyonlar, osteoporoz ve osteoartritle ilişkilendirmişlerdir ${ }^{49-51}$. Çoğunlukla eklem bölgelerine yakın görülmekle birlikte vücudun her bölgesinde oluşabilir. Lezyonlar dermiste lokalize, palpasyonda sert kıvamda, papüller şekilde, deri ile aynı renkte, asemptomatik kitlelerdir. Panoramik radyografta düzgün sınırlı, çok küçük, çeşitli sayılarda radyoopasiteler şeklinde görülür ve enostozlarla karıştııılabilirler. Yanak ya da dudakla alveoler proçes arasına yerleştirilen periapikal radyografiler ya da düşük dozla alınan yumuşak doku tekniği ile kesin lokalizasyonuna ulaşllabilir. BT ve KIBT'de ilgili kemikten uzak, sübkütanöz bölgede kalsifiye kitleler şeklinde görülür ${ }^{3,49}$.

Myositis Ossifikans; ekstremiteler ve gövdenin derin yumuşak dokularılya, kaslarda meydana gelen non-neoplastik, reaktif hiperplaziyle karakterize heterotopik ossifikasyonu ifade eder. Genellikle iskelet sistemi kaslarını etkiler, baş-boyun bölgesinde nadir olarak görülür. Klinik özellikleri ve biyolojik davranışına göre progresif, sirkümskripta ve nörojenik olmak üzere 3 sınıfa ayrılır. Çocukluk döneminde görülen progresif myositis ossifikans otozomal dominant geçişlidir. Nörojenik myositis ossifikans spinal kord yaralanmaları

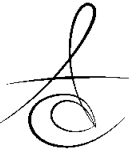


nedeniyle hareketsiz kalan hastalarda ortaya çıkan bir durumdur. Heterotopik ossifikasyon baskın olarak kalça ve diz ekleminin etrafında oluşur. Myositis ossifikans sirkümskripta sıklıkla travmayı takiben ilgili kas bölgesinde oluşur ${ }^{52,53}$. Sıklıkla ekstremiteleri etkileyen, genellikle hayatın üçüncü dekatında görülen, benign bir durumdur. Baş-boyun bölgesinde temporal, masseter, medial ve lateral pterigoid kaslarla, sternokleidomastoid kaslarda görülen vakalar bildirilmiştir. Diş çekimi, özellikle mandibular anestezi olmak üzere intraoral lokal anesteziler ve operatif işlemleri takiben oluştuğu düşünülür ${ }^{52-55}$. Oluşum mekanizması açık olmamakla birlikte teorilerden biri; travmanın, periosteal osteoblastların kasların içine doğru implantasyonunu indükleyerek intramuskular ossifikasyonu başlatması fikridir. Bununla birlikte en yaygın kabul edilen görüş; travmanın, yaralanma alanında insan kemik morfogenetik protein sentezini indükleyerek, primitif hücrelerin osteoblastlara dönüşmesini stimüle ettiği yönündedir $^{52,56}$. Klinik olarak travmayı takiben ağrı, şişlik, hassasiyet, hareket kısıtlılı̆ı gibi belirtiler ortaya çıkar. $\mathrm{Bu}$ şişlik bir süre sonra sert ve hassas bir kitleye dönüşür. Radyografik olarak travmayı takiben 2-3 hafta sonra kötü sınırlı, düzensiz, soluk opasiteler şeklinde görülür. Hasta sadece 4-6 hafta sonra karakteristik zonal kalsifikasyon ile birlikte belirgin hale gelir. Bu nedenle, üç fazlı kemik sintigrafisi veya USG formasyonun erken aşamalarında teşhis için faydalı olabilir $^{52,55}$. Ayırıcı tanıda stilohyoid ligament ossifikasyonu ve osteojenik tümörler düşünülmelidir. Lokasyon ve formasyon bakımından ligament kalsifikasyonu ndan ayrılır. Osteojenik tümörlerde de genellikle kemikte destrüksiyon vardır ${ }^{3}$.

\section{KAYNAKLAR}

1. de Moura MD, Madureira DF, Noman-Ferreira LC, Abdo EN, de Aguiar EG, Freire AR. Tonsillolith: A Report of Three Clinical Cases. Med Oral Patol Oral Cir Bucal 2007; 1:12.

2. de Oliveira Cde N, Amaral TM, Abdo EN, Mesquita RA. Bilateral Tonsilloliths and Calcified Carotid Atheromas: Case Report and Literature Review. J Craniomaxillofac Surg 2013; 41:179-82.

3. White SC, Pharoah MJ. Oral Radiology, Principles and Interpretation. 5nd Ed. Toronto;Canada: 2009. p. 597-614.
4. Zychowicz ME. Pathophysiology of Heterotopic Ossification. Orthop Nurs 2013;32:173-7.

5. Garay I, Netto HD, Olate S. Soft Tissue Calcified in Mandibular Angle Area Observed by means of Panoramic radiography. Int J Clin Exp Med 2014; 15;7:51-6.

6. Ergun $T$, Lakadamyali $H$. The Prevalence and Clinical Importance of Incidental Soft-Tissue Findings in Cervical CT Scans of Trauma Population. Dentomaxillofac Radiol 2013;42: 20130216.

7. Sezer B, Tugsel Z, Bilgen C. An Unusual Tonsillolith. Oral Surg Oral Med Oral Pathol Oral Radiol Endod 2003;95:471-3.

8. Ahuja AT, Ying M, Ho SY, Antonio G, Lee YP, King $A D$, Wong KT. Ultrasound of Malignant Cervical Lymph Nodes. Cancer Imaging 2008; 25;8:48-56.

9. Mehrian $\mathrm{P}$, Ebrahimzadeh SA. Differentiation between Sarcoidosis And Hodgkin's Lymphoma Based on Mediastinal Lymph Node Involvement Pattern: Evaluation Using Spiral CT Scan. Pol J Radiol 2013;78:15-20.

10. Aydin U. Tuberculous Lymph Node Calcification Detected on Routine Panoramic Radiography: A Case Report. Dentomaxillofac Radiol 2003; 32:2524.

11. Kraft R. Cysticercosis: An Emerging Parasitic Disease. Am Fam Physician 2007; 1;76:91-6.

12. Goyal P, Sehgal S, Ghosh S, Mittal D, Kumar A, Singh S. A Cytological Study of Palpable Superficial Nodules of Parasitic Origin: A Study of 41 Cases. Patholog Res Int 2014;2014.

13. Kanlı A. ve Özkan G. Yumuşak Dokuda Radyoopak Görüntü Veren Lezyonlar. Turkiye Klinikleri J Dental Sci-Special Topics 2010;1:58-65.

14. Singh S, Sreenivasan V, Garg K, Wazir ND, Rajput JS, Sandhu Virk P. Cysticercosis Involving Muscle of Mastication: A Review and Report of Two Cases. Case Rep Dent 2013;2013.

15. Nigam JS, Sharma A. Fine Needle Aspiration Cytology of Cysticercosis. J Clin Diagn Res. 2013;7:3123.

16. Macdonald DS, Zhang L, Gu Y. Calcification of the External Carotid Arteries and Their Branches. Dentomaxillofac Radiol 2012;41:615-8.

17. Taguchi A, Iwamoto $Y$, Yamada S, Sugino N, Kuroiwa $\mathrm{H}$, et al. Association of Carotid Artery Calcification Detected on Dental Panoramic

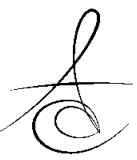


Radiographs with a History of Osteoporosis Diagnosis without Prevalent Fractures. J Radiol Radiat Ther 2013;1: 1020.

18. Tiller R, Bengel W, Rinke S, Ziebolz D. Association between carotid area calcifications and periodontal risk: a cross sectional study of panoramic radiographic findings. BMC Cardiovasc Disord 2011;9;11:67.

19. Saitoh E, Nagae Y, Wachi H, Seyama Y. Variance of Expressions of Extracellular Matrix Components and Effects of Anti-Osteoporotic Drugs on Mönckeberg's Arteriosclerosis. Yakugaku Zasshi 2008;128:385-92.

20. Brasileiro Junior VL, Luna AHB, Sales MAO, Rodrigues TLC, Sarmento PLFA, Mello Junior CF. Reliability of Digital Panoramic Radiography in the Diagnosis of Carotid Artery Calcifications. Radiol Bras 2014;47:28-32.

21. Romano-Sousa CM, Krejci L, Medeiros FM, Graciosa-Filho RG, Martins MF, GuedesVN, FenyoPereira $M$. Diagnostic agreement between panoramic radiographs and color Doppler images of carotid atheroma. J Appl Oral Sci 2009;17:45-8.

22. Kamikawa RS, Pereira MF, Fernandes A, Meurer MI. Study of the Localization of Radiopacities Similar to Calcified Carotid Atheroma by means of Panoramic Radiography. Oral Surg Oral Med Oral Pathol Oral Radiol Endod 2006;101:374-8.

23. Cakur B, Sümbüllü MA, Yilmaz AB. Dental Volumetric Tomography in the Radiological Detection of Carotid Artery Calcification. Anadolu Kardiyol Derg 2011;11:652-4.

24. Imanimoghaddam $M$, Rah Rooh $M$, Mahmoudi Hashemi E, Javadzade Blouri A. Doppler Sonography Confirmation in Patients Showing Calcified Carotid Artery Atheroma in Panoramic Radiography and Evaluation of Related Risk Factors. J Dent Res Dent Clin Dent Prospects 2012;6:6-11.

25. Chuangqi Y, Chi Y, Lingyan Z. Sialendoscopic Findings in Patients with Obstructive Sialadenitis: Long-Term Experience. Br J Oral Maxillofac Surg 2013;51:337-41.

26. Liu NM, Rawal J. Submandibular sialolithiasis in A Child. Arch Dis Child 2013;98:407.
27. Jadu FM, Lam EW. A Comparative Study of the Diagnostic Capabilities of 2D Plain Radiograph and 3D Cone Beam CT Sialography. Dentomaxillofac Radiol 2013;42:20110319.

28. Marwaha M, Nanda KD. Sialolithiasis in a 10 Year Old Child. Indian J Dent Res 2012;23:546-9.

29. Karengera D, Yousefpour A, Sadeghi HM, Reychler $\mathrm{H}$. Sialolithiasis in Children as a Diagnostic Dilemma. Eur Arch Otorhinolaryngol 2000; 257: 161-3.

30. Bar T, Zagury A, London D, Shacham R, Nahlieli O. Calcifications Simulating Sialolithiasis of the Major Salivary Glands. Dentomaxillofac Radiol 2007;36:59-62.

31. Orhan K, Icen M, Aksoy S, Avsever H, Akcicek G. Large Arteriovenous Malformation of the Oromaxillofacial Region with Multiple Phleboliths. Oral Surg Oral Med Oral Pathol Oral Radiol 2012;114:147-58.

32. Zengin AZ, Celenk $P$, Sumer AP. Intramuscular Hemangioma Presenting with Multiple Phleboliths: A Case Report. Oral Surg Oral Med Oral Pathol Oral Radiol 2013;115:32-6.

33. Turgut HB, Kadıoğlu $D$, Çalgüner $E$, Anıl A, Gözil R, Peker T, Gülekon N, Bahçelioğlu M. Anatomi Uygulama Kitabı. İnsan Vücudunun Tamamının Anlatıldığı Uygulama Kitabı, Türkiye. NM Medikal ve Nobel Yayınevi. 2010.

34. Galline J, Marsot-Dupuch K, Bigel P, Lasjaunias P. Bilateral Dystrophic Ossification of the Thyroid Cartilage Appearing as Symmetrical Laryngeal Masses. AJNR Am J Neuroradiol 2005;26:1339-41.

35. Mupparapu M, Vuppalapati A. Detection of an Early Ossification of Thyroid Cartilage in An Adolescent on A Lateral Cephalometric Radiograph. Angle Orthod. 2002;72:576-8.

36. Barros CA, Martins RR, Silva JB, Souza JB, RibeiroRotta RF, Batista AC, Mendonça EF. Rhinolith: a Radiographic Finding in a Dental Clinic. Oral Surg Oral Med Oral Pathol Oral Radiol Endod 2005;100:486-90.

37. Nair S, James E, Dutta A, Goyal S. Antrolith in the Maxillary Sinus: An Unusual Complication of Endoscopic Sinus Surgery. Indian J Otolaryngol Head Neck Surg 2010;62:81-3.

38. Brehmer D, Riemann R. The rhinolith-a possible differential diagnosis of a unilateral nasal obstruction. Case Rep Med 2010;845671.

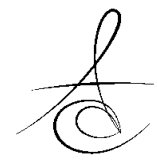


39. Shenoy V, Maller V, Maller V. Maxillary Antrolith: A Rare Cause of The Recurrent Sinusitis. Case Rep Otolaryngol 2013;527152.

40. Sumbullu MA, Tozoglu U, Yoruk O, Yilmaz AB, Ucuncu H. Rhinolithiasis: The Importance of Flat Panel Detector-Based Cone Beam Computed Tomography in Diagnosis and Treatment. Oral Surg Oral Med Oral Pathol Oral Radiol Endod 2009;107:65-7.

41. Bostan B, Erdem M, Güneş T, Şen C, Köseoğlu D. Overlooked Primary Hyperparathyroidism Presented With Fractures: Case Report. Ulus Travma Acil Cerrahi Derg 2010;16:567-70.

42. Karasu HA, Tüzüner AM, Üçok C, Brown Tumour in Secondary Hyperparathyroidism: A Case Report. Türkiye Klinikleri Diş Hekimliği Bilimleri Dergisi 2004;10: 49-52.

43. Nair $P$, Gharote $H$, Thomas $S$, Guruprasad $R$, Singh N. Brown Tumour Of The Jaw. BMJ Case Reports 2011;8:1-4.

44. Şanal $S$, Süslü $A E$, Biçer YÖ, Serin $E$, Kanat $M$. Primer Hiperparatiroidizm Ve Cerrahi Tedavisi. Kbb-Forum 2009;8:65-70.

45. MacDonald-Jankowski DS. Calcification of the Stylohyoid Complex in Londoners and Hong Kong Chinese. Dentomaxillofac Radiol 2001;30:35-9.

46. Alpoz E, Akar GC, Celik S, Govsa F, Lomcali G. Prevalence and Pattern of Stylohyoid Chain Complex Patterns Detected by Panoramic Radiographs among Turkish Population. Surg Radiol Anat 2014;36:39-46.

47. Rizzatti-Barbosa CM, Ribeiro MC, Silva-Concilio LR, Di Hipolito O, Ambrosano GM. Is An Elongated Stylohyoid Process Prevalent in the Elderly? A radiographic study in a Brazilian population. Gerodontology 2005;22:112-5.

48. Sadaksharam J, Singh K. Stylocarotid syndrome: An Unusual Case Report. Contemp Clin Dent 2012;3:503-6.

49. Bouraoui S, Mlika M, Kort R, Cherif F, Lahmar A, Sabeh M. Miliary Osteoma Cutis Of The Face. J Dermatol Case Rep 2011:12;5:77-81.

50. Jeong KH, Lew BL, Sim WY. Osteoma Cutis As The Presenting Feature Of Albright Hereditary Osteodystrophy Associated With Pseudopseudohypoparathyroidism. Ann Dermatol 2009;21:154-8.
51. Riahi RR, Cohen PR. Multiple Miliary Osteoma Cutis Of The Face After Initiation of Alendronate Therapy For Osteoporosis. Skinmed 2011; 9:258-9.

52. Wiggins RL, Thurber D, Abramovitch K, Bouquot J, Vigneswaran N. Myositis ossificans circumscripta of the buccinator muscle: first report of a rare complication of mandibular third molar extraction. J Oral Maxillofac Surg 2008;66:1959-63.

53. Kruse AL, Dannemann C, Grätz KW. Bilateral myositis ossificans of the masseter muscle after chemoradiotherapy and critical illness neuropathyreport of a rare entity and review of literature. Head Neck Oncol 2009;12:30.

54. Manzano D, Silván A, Saez J, Moreno JC. Myositis ossificans of the temporalis muscle. Case report. Med Oral Patol Oral Cir Bucal 2007;12: 277-80.

55. Trautmann F, Moura Pd, Fernandes TL, Gondak RO, Castilho JC, Filho EM. Myositis ossificans traumatica of the medial pterygoid muscle: a case report. J Oral Sci 2010;52:485-9.

56. Kaplan FS, Fiori J, DE LA Peña LS, Ahn J, Billings PC, Shore EM. Dysregulation of the BMP-4 signaling pathway in fibrodysplasia ossificans progressiva. Ann N Y Acad Sci 2006;1068:54-65.

\author{
Yazışma Adresi \\ Arş. Gör. Dt. Elif BİLGİR \\ Süleyman Demirel Üniversitesi \\ Diş Hekimliği Fakültesi, \\ Ağız, Diş ve Çene Radyolojisi A.D. \\ İSPARTA \\ TIf: 02462118921 \\ e-mail: bilgirelif04@hotmail.com
}

